Original article

\title{
Nutritional status of human T-lymphotropic virus 1 patients: A retrospective study
}

\section{A R T I C L E I N F O}

\section{Article history:}

Received 9 October 2018

Accepted 11 September 2019

\section{Keywords:}

Malnutrition

Human T-lymphotropic virus 1

Nutritional status

Food security

Undernutrition

\begin{abstract}
S U M M A R Y
Background \& aims: The nutritional status of people with human T-lymphotropic virus (HTLV-1) infection has been poorly described because it involves a neglected disease. The few studies that have been conducted mostly involve people with neurologic consequences and the possible clinical evolutions of the disease. The aim of this study was to describe the nutritional status of patients with HTLV- 1 , including those with associated myelopathy/tropical spastic paraparesis, and to evaluate food security in these patients.

Methods: A retrospective observational study was conducted in people with HTLV-1 admitted to a referral hospital. We collected data from 17 medical records, including anthropometric data (i.e., body mass index, mid-upper arm circumference, triceps skinfold, and mid-arm muscle circumference), laboratory test results (i.e., haemoglobin, haematocrit, albumin, globulin, iron fixation capacity, and iron), the Subjective Global Assessment (SGA) method, and food security (Brazilian Food Insecurity Scale) data. The data were analysed using the R-project software. To evaluate possible associations between the outcomes and predictors (age at hospitalisation, food security, presence of children $<18$ years of age living in the household, income, schooling, ANSG, BMI, difference between ideal weight and hospitalisation, TSF, MUAC ICU days, hospitalisation outcome, rehospitalisation in the first year after discharge, interval between readmissions, death, associated conditions, constipation upon admission), we used Kruskal-Wallis, Mann-Whitney, Fisher's exact, chi-square tests with continuity correction, and Spearman's correlation coefficient. Hypothesis tests were considered statistically significant when $\mathrm{p} \leq 0.05$. Results: The mean age of the patients was $57(52-60)$ years. The patients were predominantly women (59\%) and had an income lower than the local minimum wage with at least 6 years of schooling (52.3\%). Only $18.2 \%$ of patients were eutrophic according to their BMI and $23.5 \%$ of patients were malnourished based on the SGA method. Patients predominantly had food security (64.7\%) and good intestinal functions (64.7\%) during their hospital stay.

Conclusion: Despite having a limited number of patients in this study, HTLV-1 patients admitted to hospital are at high risk of malnutrition based on the scores from the SGA method.
\end{abstract}

() 2019 Published by Elsevier Ltd on behalf of European Society for Clinical Nutrition and Metabolism.

\footnotetext{
* Corresponding author

E-mail address: adriana.bacelo@ini.fiocruz.br (A.C. Bacelo).
}

\section{Introduction}

Human T-lymphotropic virus (HTLV-1)-associated myelopathy/ tropical spastic paraparesis (HAM/TSP) is a progressive disease of the central nervous system (CNS) [1] historically associated with low quality of life [2]. There are a few studies about the nutritional status of HTLV-1 patients; however, the assessment has generally 
been based on the body mass index (BMI) or the relationship between diet and intestinal function [2-4]. The Brazilian Ministry of Health recommends dietary counselling only to reduce intestinal constipation symptoms. However, the relationship between neurological and nutritional problems (i.e., malnutrition) was not evaluated or considered in the Brazilian Ministry of Health guidelines [3]. HAM/TSP patients with overweight, depression and metabolic alterations reportedly require monitoring and nutritional interventions because of the impact on the patient's daily quality of life [2]. For several decades Brazil has developed public policy actions directed at public food and nutritional security (SAN). Poverty and extreme poverty are strongly associated with food and nutritional security, because in Brazil, as in many countries, the lack of income and its unfair distribution are the main factor that prevent individuals from having access to food, although there is no shortage in food availability [5]. The aim of this study was to describe the nutritional status and evaluate food security of hospitalised patients with HTLV-1, including those with HAM/TSP.

\section{Materials and methods}

\subsection{Study design}

This is a retrospective study on a cohort of HTLV- 1 hospitalised patients performed at Evandro Chagas National Institute of infectious Diseases (INI), Fundação Oswaldo Cruz, at Rio de Janeiro, Brazil, from February 2012 to August 2013.

\subsection{Eligibility and exclusion criteria}

The inclusion criteria were adult ( $>18$ years) HTLV- 1 - infected inpatients and the exclusion criteria were: patients who refused to participate; death and hospital discharge within the first $24 \mathrm{~h}$; missing anthropometric or clinical data; inability to answer or sign the research protocols questionnaire; and homeless patients.

\subsection{Socio-demographic characteristics}

The socio-demographic characteristics (sex, age, education, monthly income, having any dependents under the age of 18 years old) of individuals with HTLV-1 was described only for characterisation of the sample.

\subsection{Nutritional status}

Anthropometric data [BMI, mid-upper arm circumference (MUAC), triceps skinfold thickness (TSF), and mid-arm muscle circumference (MAMC)], biochemical markers, and Subjective Global Assessment (SGA) of nutritional status were used to assess nutritional risk. BMI (normal range: $18.5-24.9 \mathrm{~kg} / \mathrm{m}^{2}$ ) was classified according to criteria of the World Health Organization [6]. MUAC (normal range: 28.5-29.3 cm), TSF (normal range: 11.4-18.2 $\mathrm{mm}$ ) and MAMC (normal range $21.0-27.8 \mathrm{~cm}$ ), were categorised according to Lohman (1988) [7].

Information on haematological markers, including blood count using automated optical microscopy with a reference value (RV) of 11-18 g/dL for haemoglobin and 34-54\% for haematocrit, were collected. Chromatography technique was used to measure albumin (RV, 3.4-5.0 g/dL), total protein (RV, 6.4-8.2 g/dL), globulin $(\mathrm{RV}, 2.5-4.0 \mathrm{~g} / \mathrm{dL})$, and iron fixation capacity (RV, $-250-450 \mathrm{mcg} /$ dL).

The SGA method is an effective method for identification of the at-risk patient [8]. Although anthropometric values are the traditional method used to assess nutritional risk, there is little information or consensus on whether patient with low BMI are also at risk $[9,10]$.

The SGA method [11] uses specific features of the history and physical examination. The first and second features of the patient history in SGA are weight loss in the previous 6 months before the hospitalization and any change in the patient's usual dietary pattern, respectively. Patients are classified first as having a normal or abnormal dietary intake; the duration and degree of the abnormal dietary intake are also noted. The third, fourth, and fifth features of the history are the presence of significant gastrointestinal symptoms, patient's functional capacity or energy, and metabolic demands of the patient's disease state, respectively.

Food insecurity has been defined as limited or uncertain availability of nutritionally adequate and safe foods or limited or uncertain ability to acquire acceptable foods in socially acceptable ways [12]. However, food security is a limited value as an indicator of individual food security [13], this Scale [14] has been associated with various meanings over time. In this study, we evaluated food security by combining the estimates of household food acquisition and allocation behaviour. The questions in the food security questionnaire attempted to capture perceptions as well as past experience by the households [15].

The first study endpoint was nutrition status. Individuals were not considered malnourished, at any time, if all the markers (i.e., anthropometric and laboratory) were within the RVs, as established by the Food and Agriculture Organization (FAO) of the United Nations [16]. Patients were considered to be malnourished, at any time, if at least one of the markers was outside the RVs, as established by FAO [16].

The patient's malnutrition status upon hospital admission was further classified as: (a) global, using BMI, TSF, MUAC, and serum biomarkers (total protein and albumin); (b) energy, based on BMI and TSF; and (c) protein, according to MAMC and total protein and albumin levels.

The second study endpoint was food security measured using the Brazilian Food Insecurity Scale (Fig. 1), which was proposed and validated for Brazil by Segall-Corrêa et al., in 2003 [17].

\subsection{Ethical considerations}

This study was conducted in accordance with the ethical standards outlined for research in humans. The patients had previously been recruited and signed the informed consent for the study "Food security, nutritional status and socioeconomic status of patients with infectious diseases admitted to INI/Hospital." The study was approved by the Institutional Ethics Committee (identification number CAE 0042.0.009.000-11).

\subsection{Data analysis}

Data were analysed using the R-project software, version 3.3.0. [18]. Kruskal-Wallis, Mann-Whitney, Fisher's exact, and chisquare tests with continuity correction and Spearman's correlation coefficient were used to evaluate possible associations between the outcomes (days of hospitalisation, intensive care unit -

\begin{tabular}{|c|c|}
\hline Classification & Points \\
\hline Food Safety & 0 \\
\hline Light Insecurity & $1-5$ \\
\hline Moderate Insecurity & $6-10$ \\
\hline Serious Insecurity & $11-15$ \\
\hline
\end{tabular}

Fig. 1. Brazilian Food Insecurity Scale method. 
ICU stay, intensive care unit - ICU time, outcome, hospital readmission, interval between hospitalisations, death, associated pathology, and intestinal constipation) and predictors (age, food security classification, income, schooling, SGA, BMI, difference between ideal and hospitalisation weight, TSF, and MUAC) [19]. Hypothesis tests were considered statistically significant when $\mathrm{p} \leq 0.05$.

To evaluate the associations between the predictors (age at hospitalisation, food security, presence of children $<18$ years of age living in the household, income, schooling, ANSG, BMI, difference between ideal weight and hospitalisation, TSF, MUAC ICU days, hospitalisation outcome, rehospitalisation in the first year after discharge, interval between readmissions, death, associated conditions, constipation upon admission), we used the Fisher's exact, chi-square with continuity correction, Mann-Whitney, and Kruskal-Wallis tests and Spearman's correlation where possible, as appropriate. For the readjustment in 1-year outcome, the univariate and multivariate logistic models were applied using the backward algorithm to select variables. The significance level was set at 0.05 and the statistical package used was $\mathrm{R}$ version 3.3.0.

\section{Results}

Seventeen patients (total hospitalised patients with HTLV-1 in the study period) were included in this study (Table 1 ). On the date of hospital admission, the mean age of the patients was 57 (52-60) years. The patients were predominantly women (58.8\%), had an income lower than the local minimum wage, had completed at least 6 years of schooling (52.9\%), and had good intestinal functions during the hospitalisation period (64.7\%). Food insecurity was observed in $35.2 \%(n=6)$ patients.

Only $11.8 \%(\mathrm{n}=2)$ of patients were eutrophic according to their BMI, while $76.5 \%(n=13)$ of patients fell in the normal range according to the SGA. All patients $(n=3)$ who had HTLV- 1 infection for $<10$ years were eutrophic, and only one patient who died was malnourished (Table 2). However, we did not find a relationship between readmissions $(n=4)$ and nutritional status $(n=2 / 4$ obese and $1 / 4$ undernourished) or food insecurity $(\mathrm{n}=3 / 4)$ (Table 3$)$.

Overall, $35.3 \%(n=6)$ of patients were overweight according to BMI and MUAC measurements. Although malnutrition occurred in only $23.5 \%(n=4)$ and $17.7 \%(n=3)$ of patients based on SGA and BMI, respectively, it appeared to be as common as food insecurity based on TSF (29.4\%; $n=5)$, MUAC (35.3\%; $n=6)$ and MAMC $(29.4 \% ; n=5)$ measurements. It is noteworthy that all patients had low mean albumin [2.2 g/dL; standard deviation (SD), $1.7 \mathrm{~g} / \mathrm{dL}$ ] or total protein $(5.9 \mathrm{~g} / \mathrm{dL} ; \mathrm{SD}, 2.5 \mathrm{~g} / \mathrm{dL})$ levels. No correlation was identified between the predictors (age at admission, food security,

Table 1

Socio-demographic characteristics of individuals with human T-lymphotropic virus infection.

\begin{tabular}{ll}
\hline Parameters & HTLV-1 patients $(\mathrm{n}=17)$ \\
\hline Sex, $\mathrm{n}(\%)$ & $10(58.8)$ \\
Female & \\
Age (years) & $57(52-60)$ \\
Mean (IQR) & $9(52.9)$ \\
Education, $\mathrm{n}(\%)$ & $7(41.2)$ \\
Middle school & $1(5.9)$ \\
High school & \\
Undergraduate & $330(212-555)$ \\
Monthly income & $8(47.1)$ \\
Median (IQR), US\$ & $9(52.9)$ \\
Live with someone under the age of 18 years old, $\mathrm{n}(\%)$ \\
No \\
Yes
\end{tabular}

$\mathrm{n}=$ number of patients; IQR $=$ Interquartile range.
Table 2

Outcome of hospitalisation in patients infected with HTLV-1-1.

\begin{tabular}{ll}
\hline Outcome & HTLV-1 patients $(\mathrm{n}=17)$ \\
\hline Intensive care, $\mathrm{n}(\%)$ & $16(94.1)$ \\
$\quad$ No & $1(5.9)$ \\
Yes & $15(88.2)$ \\
Hospital ward, $\mathrm{n}(\%)$ & $2(11.8)$ \\
$\quad$ Discharge & $13(76.5)$ \\
$\quad$ Death & $4(23.5)$ \\
Readmission, $\mathrm{n}(\%)$ & \\
$\quad$ No & \\
$\quad$ Yes & \\
\hline $\mathrm{n}=$ number of patients. &
\end{tabular}

living with children aged $<18$ years, income, schooling, ASG, BMI, difference between ideal weight and hospitalisation, MUAC, TSF, and MAMC) and each of the outcomes (days of hospitalisation, ICU hospitalisation, ICU days, hospitalisation outcome, 1-year rehospitalisation, interval between readmissions, and death or constipation at admission) (Table 4).

\section{Discussion}

Based on our findings, we observed that in hospitalised patients with HTLV-1 (a) obesity was as prevalent as malnutrition, (b) food insecurity was present in the study group, and (c) no relationship was found between malnutrition or food insecurity and death or readmission. Although we had a small sample size of 17 patients, this study was carried out in a national reference centre for HTLV-1, where all the patients with confirmed diagnosis are monitored individually with an evolution rate for symptomatology of $5 \%$.

In studies conducted in other countries, impaired nutritional status has been found in people with food insecurity. This new paradox that links poverty, food insecurity, and malnutrition to obesity exists because many people living in poverty, especially in low-income countries, have high calorie intake from a low quality diet which does not meet the requirements for optimal health [20]. In the present study, we observed evidence of the coexistence of undernutrition, obesity, and food insecurity in the same cohort. This is an important issue, because the different types of malnutrition will impact our ability to detect them, leading to a potential underestimation of its prevalence depending on the concept/ method used to diagnose the state of malnutrition. Therefore, diagnosis may be missed in a few patients. Malnutrition can be underestimated in the obese population. In chronic infectious diseases, such as HTLV-1 infection, the possibility of obesity coexisting with micronutrient and protein deficiency is very high due to the complications resulting from infectious diseases [21], not to mention that one study suggested an association between obesity and infection exists [22].

Malnutrition is often evaluated using different nutritional parameters, alongside anthropometric data, because these parameters are considered important in determining the clinical progression of organic changes [16]. The concept of SGA is derived from the awareness that several diseases can affect nutritional status in a variety of ways. The risks of complications or morbid events associated with these diseases or nutritional statuses are different for each malnutrition type [16].

BMI has been used in clinical practise and at research settings to describe the nutritional status of the study cohort, and was adopted by the Brazilian Ministry of Health [23,24] and World Health Organization [25] as an anthropometric index, since it is an easy method of monitoring nutritional status. Anthropometry is a universal technique that requires only portable equipment, and its application is inexpensive and non-invasive [26]. However, the 
Table 3

Relationship between readmissions, nutritional status and food insecurity in hospitalised patients infected with HTLV-1.

\begin{tabular}{|c|c|c|c|c|}
\hline & No & Yes & Statistical test & P value \\
\hline Total & 13 & 4 & & \\
\hline Age at admission & & & Ranksum test & 0.02 \\
\hline Median (IQR) & $59(57,61)$ & $48.5(44.2,52)$ & & \\
\hline Minimum income & & & Ranksum test & 0.942 \\
\hline Median (IQR) & $2.5(2,4)$ & $3(2,4)$ & & \\
\hline Education & & & Fisher's exact test & 1 \\
\hline Middle school & $7(53.9)$ & $2(50)$ & & \\
\hline High school & $5(38,4)$ & $2(50)$ & & \\
\hline Undergraduate & $1(7.7)$ & $0(0)$ & & \\
\hline Food Insecurity & & & Fisher's exact test & 1 \\
\hline Mild & $2(15.4)$ & $1(25)$ & & \\
\hline Moderate & $2(15.4)$ & $1(25)$ & & \\
\hline Severe & $9(69.2)$ & $2(50)$ & & \\
\hline$<18$ year old & & & Fisher's exact test & 0.082 \\
\hline No & $8(61.5)$ & $0(0)$ & & \\
\hline Yes & $5(38.5)$ & $4(100)$ & & \\
\hline Subjective Global Assessment & & & Fisher's exact test & 1 \\
\hline Undernutrition severe & $1(7.7)$ & $0(0)$ & & \\
\hline Undernutrition mild and moderate & $2(15.4)$ & $1(25)$ & & \\
\hline Normal & $10(76.9)$ & $3(75)$ & & \\
\hline Body mass index & & & Fisher's exact test & 0.924 \\
\hline Undernutrition severe & $1(7.7)$ & $0(0)$ & & \\
\hline Undernutrition mild and moderate & $2(15.3)$ & $0(0)$ & & \\
\hline Normal & $10(77)$ & $3(100)$ & & \\
\hline Mid-upper-arm circumference & & & Ranksum test & 0.712 \\
\hline median (IQR) & $24.5(22,32)$ & $30.6(27.8,31.1)$ & & \\
\hline Triceps skinfold & & & Ranksum test & 0.267 \\
\hline median (IQR) & $11.5(6.6,15)$ & $16.5(12.8,22)$ & & \\
\hline Mid-arm muscle circumference & & & Ranksum test & 0.712 \\
\hline median (IQR) & $20.7(19.9,27.3)$ & $22.8(22.5,24.1)$ & & \\
\hline
\end{tabular}

Table 4

Measurements of nutritional status and Food Security of in hospitalised patients with HTLV-1.

\begin{tabular}{ll}
\hline Parameters & HTLV-1 patients ( $\mathrm{n}=17)$ \\
\hline Food security method, n (\%) & \\
Food security Severe & $11(64.7)$ \\
Food insecurity mild & $3(17.6)$ \\
Food insecurity moderate & $3(17.6)$ \\
Anthropometric characteristics & \\
Subjective Global Assessment, n (\%) & $13(76.5)$ \\
Normal & $3(17.6)$ \\
Undernutrition mild and moderate & $1(5.9)$ \\
Undernutrition severe & \\
Body mass index, n (\%) & $28.44(14.8-39.1)$ \\
Median (IQR), kg/m & \\
Mid-upper-arm circumference & $27.8(22.8-31.6)$ \\
Median (IQR), cm & $11.8(7.7-16.9)$ \\
Triceps skinfold & \\
Median (IQR), mm & $22.5(20.4-25.9)$ \\
Mid-arm muscle circumference & \\
Median (IQR), cm &
\end{tabular}

$\mathrm{n}=$ number of patients; IQR $=$ Interquartile range.

criteria for establishing the nutritional status established by the Food and Drug Administration in 2013 [16] require the association with other nutrition indicators to be assessed as well. BMI is not similar to the SGA or other anthropometric measures in detecting alterations in nutritional status. If the patients were evaluated based on BMI alone, $17.7 \%$ of patients would be considered to have malnutrition. However, the BMI proved very important for the diagnosis of obesity and was well related to the mid-upper-arm circumference.

Regardless of whether patients with HTLV-1 were diagnosed with undernutrition, obesity, or food insecurity, we observed a relationship between malnutrition and death or hospital readmission. There are several factors that may have influenced the occurrence of death or readmission among HTLV-1 patients. The current study group had a low level of schooling (primarily fundamental) and an income below the local minimum wage. Therefore, the combination of these factors may have negatively influenced their nutritional status, regardless of food security.

We expected a negative correlation between nutritional status and constipation because good dietary habits are related to good nutritional status [27]; however, we did not find any correlation between nutritional status and constipation in our study.

\subsection{Limitations}

The main limitation of the study was the sample size. The lack of data, due to the low incidence of the disease in the population and low occurrence of evolution to symptomatology (only 5\% of the infected population), may have influenced the low hospitalisation rate of patients with HTLV-1 (4.4\% of total hospitalised patients with infectious diseases in the study period). Few HTLV-1 epidemiological studies have been conducted in the general population, but the average prevalence of HTLV in Brazil in donor blood banks is $0.41 \%$ nationwide [28]. Although the infection is life-long and has no cure to date [28], the prevalence of hospitalization secondary to HTLV symptomatology is low and rarely described.

However, there was no relationship between malnutrition or food insecurity and rehospitalisation or death, which suggests that either malnutrition may not be the most relevant predictor in these patients or that a greater period of nutritional monitoring during the hospitalisations of these patient is required to verify this correlation.

\section{Conclusion}

Obesity, undernutrition, and food insecurity were prevalent among HTLV-1 patients, all of which are independent markers for 
increased mortality. Further research is needed to understand this relationship and their role in adverse health outcomes.

\section{Statement of authorship}

The authors' responsibilities were as follows - Bacelo, Torres, Silva and Brito: designed the study; Bacelo, Cople-Rodrigues and Gonçalves: wrote the first draft of the manuscript; Cardoso, CopleRodrigues, Silva, Santo and Almeida: identified and extracted relevant articles; Quintana: analysed the data; all authors interpreted the data, helped prepare the manuscript, and approved the final version.

\section{Conflict of interest statement}

The authors declare no conflict of interest.

\section{Funding}

This research did not receive any specific grant from funding agencies in the public, commercial, or not-for-profit sectors. Juliana Lauar Gonçalves was a CAPES/FIOCRUZ fellow.alves was a CAPES/ FIOCRUZ fellow.

\section{Acknowledgements}

We thank INI hospital nutrition team who helped with data collection.

\section{References}

[1] Bangham CRM, Araujo A, Yamano Y, Taylor GP. HTLV-1-associated myelopathy/tropical spastic paraparesis. Nat Rev Dis Primer 2015;1:15012 [Internet]. 18 de junho de [citado 5 de janeiro de 2017] Disponível em: http://www. nature.com/articles/nrdp201512.

[2] Carvalho CL, Mastequin TF, Marcusso R, Gascón MR, Santos RF, Casseb J, et al. Nutritional status and behavioral factors of individuals with HTLV-1 and tropical spastic paraparesis (HAM/TSP). Retrovirology 2015;12(Suppl 1):P72 [Internet] [citado 5 de janeiro de 2017]. 28 de agosto deDisponível em, http:// www.ncbi.nlm.nih.gov/pmc/articles/PMC4578127/.

[3] de Castro-Costa CM, Araújo AQ-C, Menna-Barreto M, Penalva-de-Oliveira AC. Guide of clinical management of HTLV patient: neurological aspects. Arq Neuropsiquiatr 2005;63(2B):548-51 [Internet] [citado 10 de maio de 2016] Disponível em, http://www.scielo.br/scielo.php?pid=S0004-282X200500030 0036\&script $=$ sci_arttext.

[4] Toste FP, Bacelo A, de Carlos Capelli J, de Moraes VM, Porte A, Pereira SEA, et al. A Contribuição da Nutrição nos casos de Paraparesia Espástica Tropical por HTLV-I. 2007 [citado 13 de janeiro de 2017]; Disponível em, http://apl. unisuam.edu.br/augustus/pdf/ed24/rev_augustus_ed_24_01.pdf.

[5] Custódio MB. Política Nacional de Segurança Alimentar e Nutricional no Brasil: arranjo institucional e alocação de recursos [PhD Thesis]. Universidade de São Paulo; 2009.

[6] WHO expert committee on physical status: the use and interpretation of anthropometry, organizador. Physical status: the use and interpretation of anthropometry: report of a WHO expert committee. Geneva: World Health Organization; 1995. p. 452 [WHO technical report series].

[7] Lohmann TG, Roche AF, Martorell R. Anthropometric standardization reference manual. Champaign, Ill.: Human Kinetics Books; 1988. p. 192.

[8] Smith RC, Ledgard JP, Doig G, Chesher D, Smith SF. An effective automated nutrition screen for hospitalized patients. Nutrition 2009;25(3):309-15 [Internet]. março de [citado 3 de julho de 2019] Disponível em, https:// linkinghub.elsevier.com/retrieve/pii/S0899900708004139.

[9] Mowry EM, Waubant E, McCulloch CE, Okuda DT, Evangelista AA, Lincoln RR, et al. Vitamin $D$ status predicts new brain magnetic resonance imaging activity in multiple sclerosis. Ann Neurol 2012;72(2):234-40 [Internet]. [citado 30 de abril de 2016] 1o de agosto de Disponível em, http://onlinelibrary. wiley.com/doi/10.1002/ana.23591/abstract.

[10] Abd Aziz NAS, Fahmi Teng NI Mohd, Kamarul Zaman M. Geriatric Nutrition Risk Index is comparable to the mini nutritional assessment for assessing nutritional status in elderly hospitalized patients. Clin Nutr ESPEN 2019;29: 77-85 [Internet].[citado 3 de julho de 2019] fevereiro de Disponível em, https://linkinghub.elsevier.com/retrieve/pii/S2405457718300238.

11] Detsky AS, Baker JP, Johnston N, Whittaker S, Mendelson RA, Jeejeebhoy KN, et al. What is subjective global assessment of nutritional status? J Parenter Enter Nutr 1987;11(1):8-13 [Internet] [citado 18 de janeiro de 2017] Disponível em, http://pen.sagepub.com/content/11/1/8.short.

[12] Kaiser LL, Lamp CL, Johns MC, Sutherlin JM, Harwood JO, Melgar-Quiñonez HR. Food security and nutritional outcomes of preschool-age Mexican-American children. J Am Diet Assoc 2002;102(7):924-9 [Internet]. julho de [citado 3 de julho de 2019] Disponível em, https://linkinghub.elsevier.com/retrieve/pii/ S0002822302902105.

[13] Pinstrup-Andersen P. Food security: definition and measurement. Food Secur 2009;1(1):5-7 [Internet].[citado 3 de julho de 2019] fevereiro de Disponível em, http://link.springer.com/10.1007/s12571-008-0002-y.

[14] Segall-Corrêa AM, Marin-Leon L. A Segurança Alimentar no Brasil: proposição e Usos da Escala Brasileira de Medida da Insegurança Alimentar (EBIA) de 2003 a 2009. Segur Aliment E Nutr 2009;16(2):1-19 [Internet] [citado 18 de janeiro de 2017] Disponível em, http://periodicos.sbu.unicamp.br/ojs/index. php/san/article/view/8634782.

[15] Pinstrup-Andersen P. Food security: definition and measurement. Food Secur 2009;1(1):5-7 [Internet].[citado 18 de janeiro de 2017] 1o de fevereiro deDisponível em, http://link.springer.com/article/10.1007/s12571-0080002-y.

[16] State of food and agriculture 2013: food systems for better nutrition. Food \& Agriculture Org; 2013.

[17] Segall Corrêa AM, escamilla RP, Maranha LK, Sampaio MFA. InsegurançaAlimentar no Brasil: validação de metodologia para acompanhamento avaliação. São Paulo: UNICAMP; 2003. p. 49 [Internet] [citado 13 de janeiro de 2017] Disponível em, http://189.28.128.100/nutricao/docs/geral/validacao_ rural_urbano.pdf.

[18] Core Team. R: a language and environment for statistical computing. 2016 Vienna, Austria. [Internet] [citado 4 de janeiro de 2017]. Disponível em: https://www.R-project.org/.

[19] de Medronho RA, Bloch KV, Luiz RR, Werneck GL. Epidemiologia. São Paulo: Atheneu; 2009.

[20] Tanumihardjo SA, Anderson C, Kaufer-Horwitz M, Bode L, Emenaker NJ, Haqq AM, et al. Poverty, obesity, and malnutrition: an international perspective recognizing the paradox. J Am Diet Assoc 2007;107(11):1966-72 [Internet]. 10 de novembro de [citado 26 de dezembro de 2017] Disponível em, http://www.sciencedirect.com/science/article/pii/S0002822307016173.

[21] Schaible UE, Kaufmann SHE. Malnutrition and infection: complex mechanisms and global impacts. PLoS Med 2007;4(5) [Internet]. maio de Disponível em: https://www.ncbi.nlm.nih.gov/pmc/articles/PMC1858706/.

[22] Obesity and infection - ScienceDirect. Available in: https://www.sciencedirect com/science/article/pii/S1473309906705230.

[23] Ministério da Saúde do Brasil. Manual de recomendações para o controle da tuberculose no Brasil. Brasília, DF: Ministério da Saúde; 2011. p. 284 (A. Normas e Manuais Técnicos).

[24] Ministério da Saúde do Brasil, Programa Nacional de Doenças Sexualmente Transmissíveis/AIDS (Brazil). Manual clínico de alimentação e nutrição na assistência a adultos infectados pelo HIV. Brasília, DF: Ministério da Saúde 2006.

[25] WHO. Guideline: nutritional care and support for patients with tuberculosis 2013 [citado 25 de fevereiro de 2014]; Disponível em: https://extranet.who. int/iris/restricted/handle/10665/94836.

[26] Ministério da Saúde do Brasil. Vigilância alimentar e nutricional - SISVAN: orientações básicas para a coleta, o processamento, a análise de dados e a informação em serviços de saúde. Brasília, DF: Ministério da Saúde, Secretaria de Atenção à Saúde, Departamento de Atenção Básica, Coordenação-Geral da Política de Alimentação e Nutrição; 2004.

[27] Nutritional Status and Constipation Rate among Female College Students Practicing Weight Control. Available in: http://agris.fao.org/agris-search search.do?recordID=KR2015004740.

[28] Galvão Castro. Distribution of human T-lymphotropic virus type I among blood donors: a nationwide Brazilian study. Transfusion - Wiley Online Library; 1997 [Internet] [citado 3 de julho de 2019]; Disponível em: https:// onlinelibrary.wiley.com/doi/epdf/10.1046/j.1537-2995.1997.37297203532.x. 